\title{
PUSAT PENANGGULANGAN BENCANA KABUPATEN SINTANG
}

\author{
Gaudensius Waldi Fernando', Emilya Kalsum², Jawas Dwijo Putro ${ }^{3}$ \\ ${ }^{1}$ Mahasiswa, Jurusan Arsitektur, Fakultas Teknik, Universitas Tanjungpura, \\ waldifernando2000@gmail.com \\ ${ }^{2}$ Jurusan Arsitektur, Fakultas Teknik, Universitas Tanjungpura \\ ${ }^{3}$ Jurusan Studi Arsitektur, Fakultas Teknik, Universitas Tanjungpura
}

Naskah diajukan pada: 24 Juni 2021

Naskah revisi akhir diterima pada: 3 Juli 2021

\begin{abstract}
Abstrak
Kondisi alam serta adanya keanekaragaman penduduk dan budaya di Indonesia menyebabkan timbulnya risiko terjadinya bencana Alam, bencana Sosial dan kedaruratan yang kompleks. Pelaksanaan tanggap darurat juga sering kali kurang mendukung, distribusi bantuan dan pelayanan kurang cepat, kurang merata serta sulit terpantau dengan baik, sehingga kemajuan hasil kegiatan tanggap darurat bencana kurang terukur secara objektif. Pada Kabupaten Sintang, selain bencana Alam, bencana Sosial juga kerap terjadi, dikarenakan wadah yang belum terstandardisasi dan mewadahi sehingga mengakibatkan pelayanan tidak maksimal. Dilihat dari kebutuhan yang ada, Pusat Penanggulangan Bencana merupakan sarana yang dapat membantu pelaksanaan kegiatan Tanggap Darurat Bencana di Kabupaten Sintang. Pusat Penanggulangan Bencana dapat mewadahi aktivitas tanggap darurat bencana sehingga memiliki jalur komando strategis supaya kesimpang siuran informasi dapat diminimalisir sehingga mewujudkan kebijakan tepat dalam menangani bencana. Pusat Penanggulangan Bencana yang direncanakan ini adalah sebuah fasilitas yang berfungsi untuk mewadahi instansi terkait penanggulangan pra dan pasca bencana baik sebagai wadah manajemen penanganan bencana maupun pusat informasi. Metode perancangan Pusat Penanggulangan Bencana ini menggunakan perbandingan literatur-literatur serta melakukan pengolahan data guna menguraikan proses perancangan Pusat Penanggulangan Bencana Kabupaten Sintang. Massa bangunan dibagi menjadi tiga bagian dipisahkan berdasarkan fungsi dan tujuan. Pendekatan pada perancangan menerapkan konsep terpadu, mengacu pada tata ruang yang terstandardisasi dan mewadahi.
\end{abstract}

Kata-kata Kunci: Bencana, Pusat Penanggulangan Bencana dan Kabupaten Sintang

\begin{abstract}
Natural conditions as well as the diversity of population and culture in Indonesia cause the risk of natural disasters, social disasters and complex emergencies to arise. The implementation of emergency response is also often not supportive, the distribution of aid and services is not fast, uneven and difficult to monitor properly, so that the progress of the results of disaster emergency response activities is less objectively measurable. In Sintang Regency, in addition to natural disasters, social disasters also often occur, because the facilities are not standardized and accommodated so that services are not optimal. Judging from the existing needs, the Disaster Management Center is a facility that can assist the implementation of Disaster Emergency Response activities in Sintang Regency. The Disaster Management Center can accommodate disaster emergency response activities so that it has strategic command lines so that information confusion can be minimized so as to realize appropriate policies in dealing with disasters. The planned Disaster Management Center is a facility that functions to accommodate agencies related to pre-and post-disaster management, both as a place for disaster management and as an information center. The design method for this Disaster Management Center uses a comparison of literatures and performs data processing to describe the design process of the Sintang Regency Disaster Management Center. The mass of the building is divided into three parts separated by function and purpose. The approach to design applies an integrated concept, referring to a standardized and accommodating spatial layout.
\end{abstract}

Keywords: Disaster, Disaster Management Center and Sintang Regency 


\section{Pendahuluan}

Bencana merupakan suatu urgensi bagi Indonesia karena tidak terdapat otoritas yang bersifat instruktif maupun finansial guna menggerakkan seluruh sektor penanganan bencana. Penanggulangan bencana merupakan tanggung jawab utama Pemerintah Daerah. Tanggap darurat bencana melibatkan elemen masyarakat dan dunia usaha, sebagaimana dikutip dalam Undang-Undang Republik Indonesia nomor 4 tahun 2007 tentang Penanggulangan Bencana. Konsep Pengurangan Risiko Bencana melihat bencana sebagai sebuah permasalahan kompleks yang menuntut adanya penanganan kolektif yang melibatkan berbagai disiplin dan kelompok kelembagaan yang berbeda dikutip dalam Peraturan Kepala Badan Nasional Penanggulangan Bencana nomor 4 tahun 2008 tentang Pedoman Penyusunan Rencana Penanggulangan Bencana. Menurut Susetyo (2012) Pemerintah melalui Badan Nasional Penanggulangan Bencana (BNPB) yang merupakan wadah dapat menetapkan regulasi yang mengatur secara lengkap prinsip-prinsip penanganan bencana lengkap dengan langkah-langkah penanganan di tahap sebelum bencana (pre disaster phase), selama bencana (impact phase), dan pasca bencana (post disaster phase). Pemerintah harus fokus dalam pengembangan kebijakan-kebijakan di bidang manajemen penanganan bencana dan mempersiapkan strategi yang harus diterapkan dalam meminimalisir kerugian ekonomi dan korban jiwa apabila terjadi bencana. Pemerintah harus dapat menjalankan peran dan fungsi baik sebagai koordinator, pelaksana maupun komando dalam proses penanggulangan bencana.

Kabupaten Sintang sudah memiliki wadah untuk penanggulangan bencana. Hanya saja, Kantor BPBD Kabupaten Sintang tidak memenuhi standar kebutuhan ruang serta aktifitas di dalamnya belum terpenuhi, menyebabkan kinerja dan pelayanan yang kurang maksimal. Hal ini perlu dilakukan perubahan sesuai dengan perkembangan serta kebutuhan masyarakat. Kabupaten Sintang selain terjadi bencana yang disebabkan oleh alam, potensi bencana sosial juga kerap terjadi di Kabupaten Sintang yang disebabkan oleh masyarakat yang mendiami daerah sekitar. Pusat Penanggulangan Bencana Daerah yang direncanakan berupa fasilitas yang berfungsi sebagai wadah pusat informasi tentang penanggulangan dan potensi bencana dalam bentuk upaya pemerintah dalam pencegahan, mitigasi, tanggap darurat, darurat sipil. Pusat Penanggulangan Bencana juga dapat melakukan rehabilitasi pra dan pasca bencana serta melaksanakan kegiatan secara terencana, terpadu, dan menyeluruh untuk masyarakat dalam menghadapi bencana, khususnya di daerah Kabupaten Sintang, Kalimantan Barat.

\section{Kajian Pustaka}

Bencana adalah suatu peristiwa atau rangkaian peristiwa yang dapat mengancam dan mengganggu penghidupan masyarakat oleh faktor alam maupun non alam bahkan faktor manusia, sehingga dapat mengakibatkan timbulnya korban jiwa, kerusakan lingkungan, kerugian harta benda dan dampak psikologis dikutip dalam Undang-Undang Republik Indonesia nomor 4 tahun 2007 tentang Penanggulangan Bencana Pasal 1 Ayat 1.

Pusat Penanggulangan Bencana Daerah merupakan objek rancangan yang berfungsi guna koordinasi segala perencanaan kemungkinan bencana, pelaksanaan kegiatan penanganan bencana dan kedaruratan secara terpadu dan melaksanakan penanganan bencana dan kedaruratan mulai dari sebelum, pada saat dan setelah terjadinya bencana yang meliputi pencegahan, kesiapan, penanganan darurat dan pemulihan, mulai dari lingkup makro maupun mikro dan objek sebagai pemantau segala aktivitas kejadian alam dikutip dalam Peraturan Kepala Badan Nasional Penanggulangan Bencana Nomor 4 tahun 2008 tentang Pedoman Penyusunan Rencana Penanggulangan Bencana.

Badan Penanggulangan Bencana memiliki fungsi yaitu perumusan dan penetapan kebijakan penanggulangan bencana dan penanganan pengungsi dengan bertindak cepat dan tepat serta efektif dan efisien dan pengkoordinasian pelaksanaan kegiatan penanggulangan bencana secara terencana, terpadu dan menyeluruh. Berdasarkan Peraturan Presiden Republik Indonesia nomor 1 tahun 2019 tugas utama dari Badan Penanggulangan Bencana yaitu memberi pedoman dan pengarahan terhadap usaha penanggulangan bencana yang mencakup pencegahan, penanganan keadaan darurat, rehabilitasi 
dan rekontruksi secara adil dan setara. Selain itu yaitu menetapkan standarisasi kebutuhan penyelenggaraan penanggulangan bencana berdasarkan peraturan perundang-undangan serta menyampaikan informasi kegiatan penanggulangan bencana kepada masyarakat.

Menurut Undang-Undang Republik Indonesia nomor 24 tahun 2007 tentang Penanggulangan Bencana bahwa Negara Kesatuan Republik Indonesia Pemerintah Pusat bertanggung jawab melindungi segenap bangsa Indonesia dan seluruh tumpah darah Indonesia dengan tujuan dapat memberikan perlindungan terhadap kehidupan dan penghidupan termasuk perlindungan dari bencana. Berdasarkan Peraturan Kepala Badan Nasional Penanggulangan Bencana nomor 17 tahun 2009, pedoman Standarisasi Peralatan Penanggulangan Bencana, agar penyelenggaraan penanggulangan bencana dapat berjalan dengan baik dan lancar, dan pada gilirannya penanggulangan bencana yang cepat dan tepat dapat direalisasikan dan korban akibat bencana dapat diminimalisir.

\section{Metode}

Perancangan Pusat Penanggulangan Bencana Kabupaten Sintang menggunakan metode yang membandingkan literatur-literatur guna menguraikan proses perancangan tersebut. Penggunaan studi literatur untuk mengetahui standar hingga fasilitas yang nantinya akan digunakan untuk perancangan. Pengumpulan data melalui observasi literatur serta melakukan pengambilan data secara langsung pada lokasi perancangan.

Setelah itu dilakukan pengolahan data dengan menggunakan metode Whittaker menurut Catanese \& Snyder (1989) pengolahan data terdiri dari tahan awal, tahap definisi, tahan persiapan, tahap analisis, tahap sintesis, tahap evaluasi dan tahap re-evaluasi yang menghasilkan alternatif dan solusi spesifik berdasarkan objek. Hasil dari analisis nantinya menghasilkan konsep dasar perancangan, konsep tapak, konsep bentuk. konsep ruang, konsep struktur serta konsep utilitas. Kemudian analisis beserta konsep ditransformasikan ke dalam bentuk gambar kerja untuk mendapatkan hasil rancangan yang maksimal.

\section{Hasil dan Pembahasan Lokasi Perancangan}

Lokasi perancangan berada di Jl. M.T Haryono, Kapuas Kanan Hulu, Kecamatan Sintang, Kabupaten Sintang. Lokasi tersebut memiliki lahan total sebesar $18.241 \mathrm{~m} 2$ dan pemanfaatan ruangnya yaitu Jasa dan Komersial. Potensi lahan tersebut yaitu memiliki aksesibilitas dan sarana pendukung yang baik.

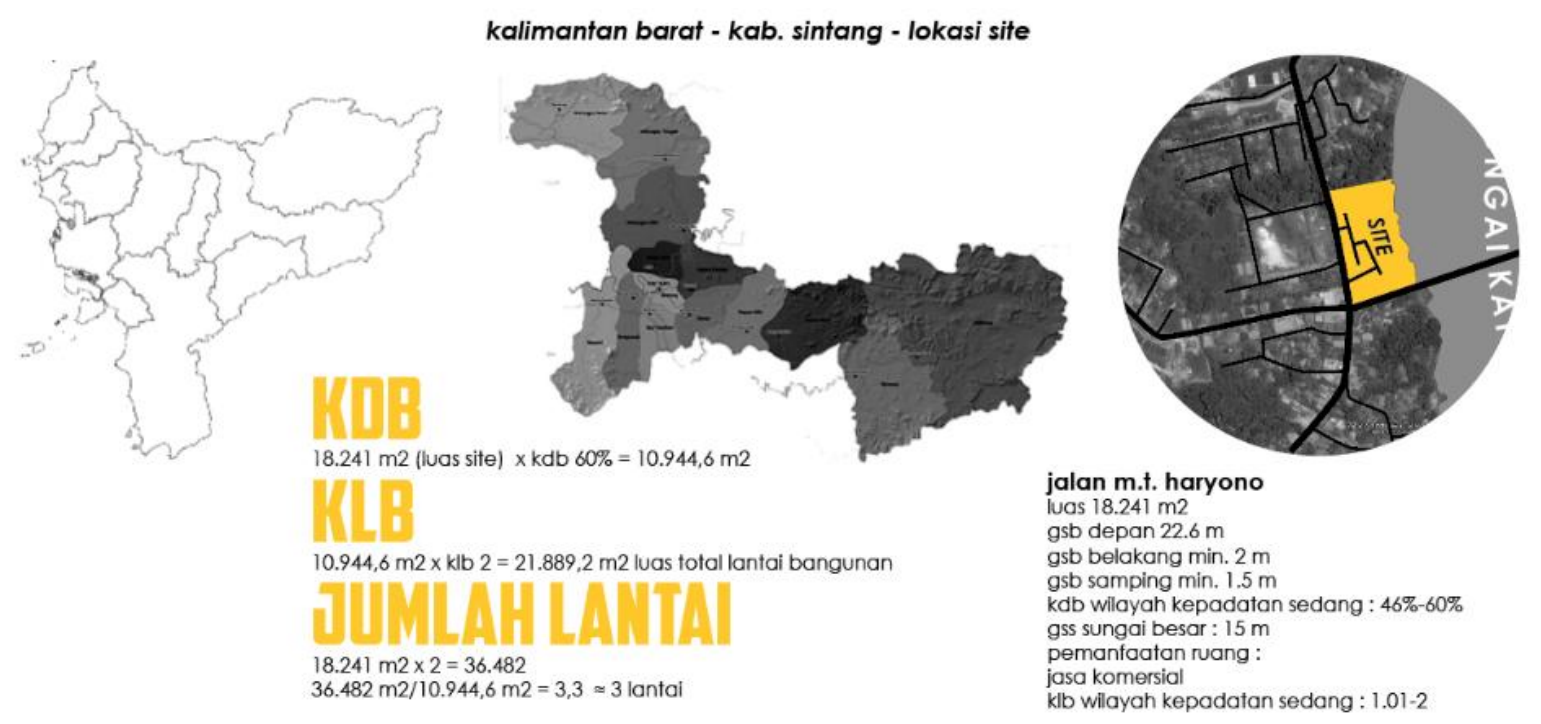

Gambar 1. Lokasi Perancangan

Sumber: Penulis, 2021 


\section{Landasan Konseptual}

Landasan Konseptual merupakan proses analisis yang menghasilkan konsep perancangan Pusat Penanggulangan Bencana. Analisis merupakan proses guna mendapatkan permasalahan dan menemukan solusi dengan cara analisis dan observasi. Fungsi utama dari bangunan merupakan sebagai wadah yang menjadi pusat koordinasi dalam pelaksanaan, penyelenggaraan penanggulangan bencana, baik dalam situasi pra bencana, pasca bencana maupun tanggap bencana serta sebagai wadah pengetahuan dalam proses tanggap bencana.

Analisa peletakan adalah penataan ulang untuk tata letak bangunan dan ruang berdasarkan fungsi dan tujuan guna segala kegiatan dan aktivitas pengguna dapat saling terhubung dan afektif dalam Penanggulangan Bencana. Selain terhubung antar tata letak bangunan berdasarkan fungsi, peletakan juga mengacu kepada peraturan Garis Sempadan Bangunan, Garis Sempadan Sungai serta Koefisien Dasar Bangunan yang mempengaruhi tata letak massa bangunan. Analisis Orientasi adalah untuk mendapatkan arah hadap bangunan sebagai respon atas fungsi sebagai Pusat Penanggulangan Bencana. Pada perancangan dapat mencapai suatu bukaan yang menjadi point of Pinterest dari bangunan maupun dari luar site. Tujuan dari analisa sirkulasi ini guna mendapatkan pola sirkulasi yang merespon fungsi dan tujuan baik sirkulasi utama untuk pencapaian site maupun sirkulasi dalam site sehingga tidak membuat para pengguna bingung, serta tidak terjadi sirkulasi silang antar jalur sirkulasi pengunjung dan pengelola Penanggulangan Bencana. Analisis vegetasi adalah menunjukkan area yang sudah terdapat vegetasi dan yang membutuhkan vegetasi lebih sebagai respon terhadap fungsi bangunan. Ragam vegetasi juga mempertimbangkan fungsi dari vegetasi yang digunakan serta memanfaatkan potensi dari vegetasi sehingga dapat menunjang aktifitas pada site maupun bangunan. Tujuan dari Analisis Zonasi guna dapat memisahkan massa berdasarkan fungsi dan kebutuhan untuk tata letak sesuai dengan tingkat privasi juga merespon terhadap lingkungan sekitar dengan fungsi bangunan sebagai Penanggulangan Bencana.

Besaran ruang dapat diperoleh setelah menentukan kebutuhan ruang yang disesuaikan dengan fungsi ruang, sirkulasi serta jumlah perabot. Standar besaran ruang didapat berdasarkan hitungan dari sumber (Neufert, 1996) dan (Neufert, 2002) serta analisis penulis. Besaran ruang dapat dilihat pada Table 1.

Tabel 1. Besaran Ruang Pusat Penanggulangan Bencana Kabupaten Sintang

\begin{tabular}{|c|c|}
\hline Fungsi & Besaran \\
\hline BPBD & 499,122 \\
\hline Pusdalops-PB & 234,022 \\
\hline Pos Komando & 1190,722 \\
\hline Pergudangan & 1294,722 \\
\hline Parkiran & 489,3681 \\
\hline Fasilitas Kendaraan Khusus & 1159,92409 \\
\hline Servis dan Keamanan & 236,457 \\
\hline Fasilitas Pengunjung & 605,8 \\
\hline Total Luas & 5719,13719 \\
\hline & $\approx 5720 \mathrm{~m}^{2}$ \\
\hline
\end{tabular}

Sumber: Penulis, 2021

Pusat Penanggulangan Bencana Kabupaten Sintang memiliki 4 fungsi yang berbeda dan dibagi menjadi 3 bangunan. Fungsi utama yaitu Kantor Badan Penanggulangan Bencana Daerah (BPBD). Kantor BPBD berhubungan langsung dengan area publik pada area parkir, kemudian berhubungan langsung dengan bangunan pendukung seperti Pos Komando, Media Center, Pusat Pelatihan dan Pendidikan serta bagian Servis.

Fungsi pendukung lainnya yaitu Bagian Pos Komando yang berfungsi sebagai pergerakan saat terjadi pra bencana ataupun pasca bencana yang memberikan kemudahan. Setelah itu terdapat fungsi 
sebagai Pusat Pengendalian Operasi Penanggulangan Bencana (Pusdalops PB) yang bertugas mengelola data dan informasi hingga menyebar luaskan kepada pejabat berwenang maupun masyarakat melalui media. Fungsi terakhir yaitu pergudangan yang difungsikan untuk penyimpanan dan pendistribusian serta berhubungan langsung dengan ruang obat-obatan yang menjadi kebutuhan setelah terjadi bencana.

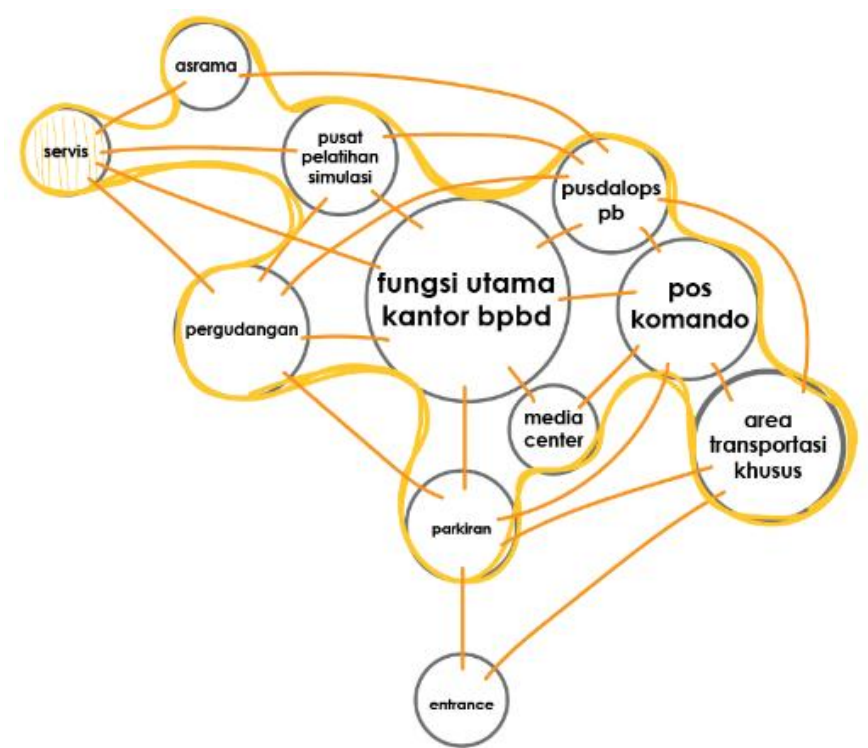

Gambar 2. Hubungan dan Organisasi Ruang Makro

Sumber: Penulis, 2021

Proses transformasi bentuk dimulai dari ide bentuk persegi yang menjadi dasar awal pembentukan massa bangunan yang mengutamakan penyesuaian dengan bentuk lahan sehingga ruang di dalamnya maupun di luar dapat dimanfaatkan secara maksimal. konfigurasi antara bentuk dasar yang di desain guna memaksimalkan tapak dan fungsi tata ruang serta massa berdialog dengan konteks di sekitarnya sehingga memberikan kesatuan antara bangunan satu dengan yang lain. Bentukan diambil dari fungsi tata ruang yang maksimal, kemudian dibagi menjadi tiga bagian. Kemudian, dari bentukan dasar tersebut dibentuk menjadi bentukan massa bangunan, selanjutnya ketiga bagian tersebut dibagi dan dipisahkan guna membentuk sebuah sirkulasi.

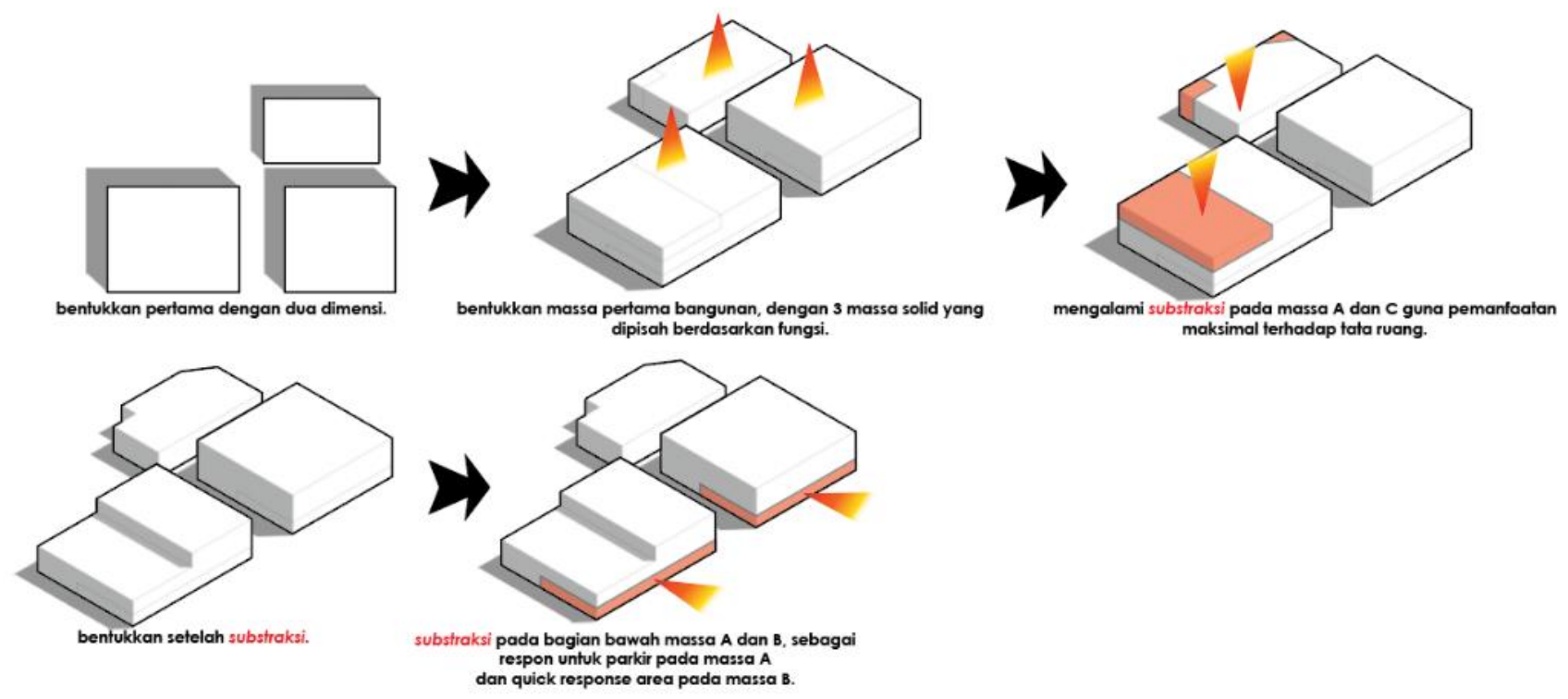

Gambar 3. Gubahan Bentuk

Sumber: Penulis, 2021 
Skematik ruang luar merupakan pembagian zonasi terhadap ruang pada site dan penyesuaian terhadap lingkungan sekitar berdasarkan tingkat privasi dan jenis kegiatan pada setiap massa maupun ruang pada bangunan. Pada bagian dalam site dibagi menjadi 3 zonasi yaitu zona publik pada bagian depan dan samping yang diperuntukkan sebagai sirkulasi dan area parkir yang digunakan secara massal, kemudian pada bagian tengah diperuntukkan untuk zona privat dan semi privat dengan mengacu kepada fungsi bangunan sebagai perkantoran, kemudian bagian belakang diperuntukkan sebagai area servis dengan fungsi pergudangan dan ruang servis lainnya, bagian belakang juga sebagai sirkulasi pada site dengan sirkulasi yang memutar namun tidak terdapat sirkulasi menyilang.

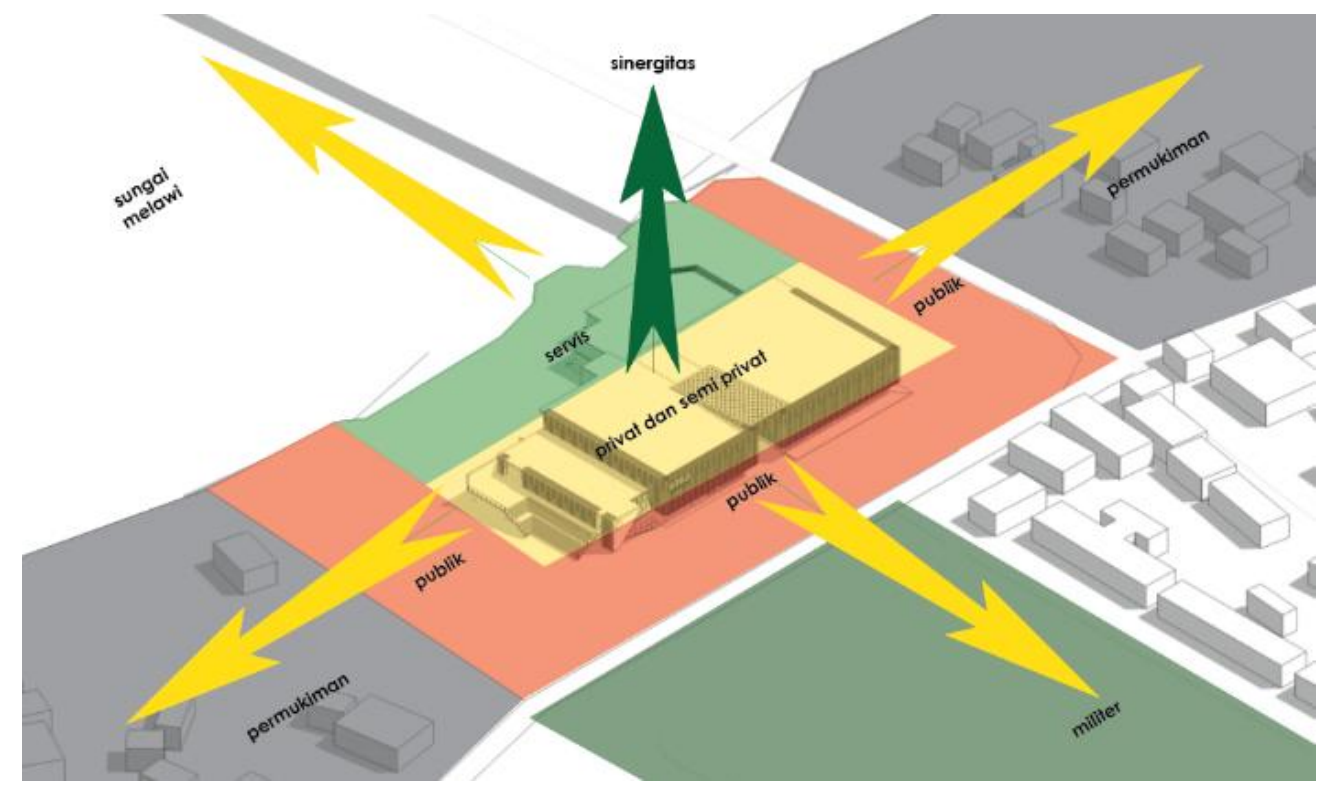

Gambar 4. Skematik Ruang Luar Sumber: Penulis, 2021

Struktur pada bangunan Pusat Penanggulangan Bencana Kabupaten Sintang ini menggunakan rangka portal dengan struktur baja kombinasi dengan beton bertulang dengan menggunakan beton komposit. Struktur bawah yaitu pondasi menggunakan pondasi telapak beton bertulang dan diperkuat denga bore pile yang merespon terhadap daya dukung tanah yang rendah, struktur bawah juga menyesuaikan dengan bentuk desain perancangan.

Tabel 2. Kriteria Pemilihan Jenis Pondasi

\begin{tabular}{lccc}
\hline \multicolumn{1}{c}{ Kriteria } & Sumur & Tiang Pancang & Plat \\
\hline SDM & 1 & 2 & 3 \\
\hline Biaya & 1 & 3 & 2 \\
\hline Tinggi Bangunan & 1 & 2 & 3 \\
\hline Kekuatan Menahan Beban & 2 & 3 & 1 \\
\hline Penyesuaian Lokasi & 1 & 3 & 2 \\
\hline \multicolumn{1}{c}{ Total Nilai } & $\mathbf{6}$ & $\mathbf{1 3}$ & $\mathbf{1 1}$ \\
\hline
\end{tabular}

Sumber: Penulis, 2021

Konsep air bersih pada perancangan Pusat Penanggulangan Bencana Kabupaten Sintang terdiri dari 2 sistem yaitu sistem serta sistem downfeet. Konsep upfeet digunakan untuk solusi bila terjadi musibah yang berkelanjutan sehingga pasokan air bersih bisa di proses secara mandiri. Sistem downfeet digunakan pada tiap fasilitas bangunan. pada sistem ini, air bersih yang telah ditampung di 
dalam reservoir atas pada masing-masing fasilitas bangunan kemudian disalurkan menuju tiap ruangan yang membutuhkan dengan memanfaatkan gaya gravitasi.

Air kotor pada perancangan Pusat Penanggulangan Bencana Kabupaten Sintang ini terdiri dari tiga jenis, yaitu air kotor dari lavatory, air kotor dari kloset dan urinoir, dan air kotor dari dapur/pantri. Air kotor lavatory yaitu buangan dari bak yang mengandung sabun dan detergen, air kotor dari buangan kloset dan urinoir, yang mengandung kotoran manusia, air kotor dari wastafel dapur yang biasanya mengandung lemak dan sisa makanan.

\section{Hasil}

Rancangan kawasan Pusat Penanggulangan Bencana Kabupaten Sintang meliputi bangunan utama yang diperuntukkan sebagai fungsi perkantoran BPBD Kabupaten Sintang dan lembagalembaga yang terkait dengan upaya penanggulangan bencana terkait membantu dalam penanggulangan bencana. Area bangunan utama meliputi akses entrance utama, jalur keluar masuk kawasan dengan memiliki akses primer dan sekunder pintu bangunan utama dan pintu keluar dengan arah yang sama, hal ini bermaksud guna memudahkan pemantauan kegiatan publik, mengingat bangunan lainnya yang memiliki akses terbatas oleh publik dengan pertimbangan tingkat privasi seperti Quick Response Area dan area pergudangan.

Bangunan pendukung B berupa fungsi Pos Komando, Pusdalops-PB dan Quick Response disertai dengan pusat pelatihan, bangunan ini memiliki dua akses utama akses berupa akses keluar masuk dan akses khusus yang hanya dilewati oleh kendaraan penanggulangan bencana dan kendaraan khusus baik di situasi normal maupun keadaan saat tanggap darurat. Akses ini bersifat privat khusus yang selalu bebas hambatan dan clear area 1x24 jam. Bangunan Pendukung C merupakan area pergudangan dan terhubung langsung dengan loading dock dan jalur aksesibilitas untuk kendaraan darat seperti mobil box, kontainer, dan mobil angkut lainnya dan loading dock dari jalur sungai sebagai area penerima pendistribusian dari kapal laut. Bangunan Pendukung $\mathrm{C}$ ini bersifat servis area sebagai area penyimpanan buffer stock penanggulangan bencana. Bangunan $\mathrm{C}$ juga sebagai tempat kendaraankendaraan berat untuk penanggulangan bencana.

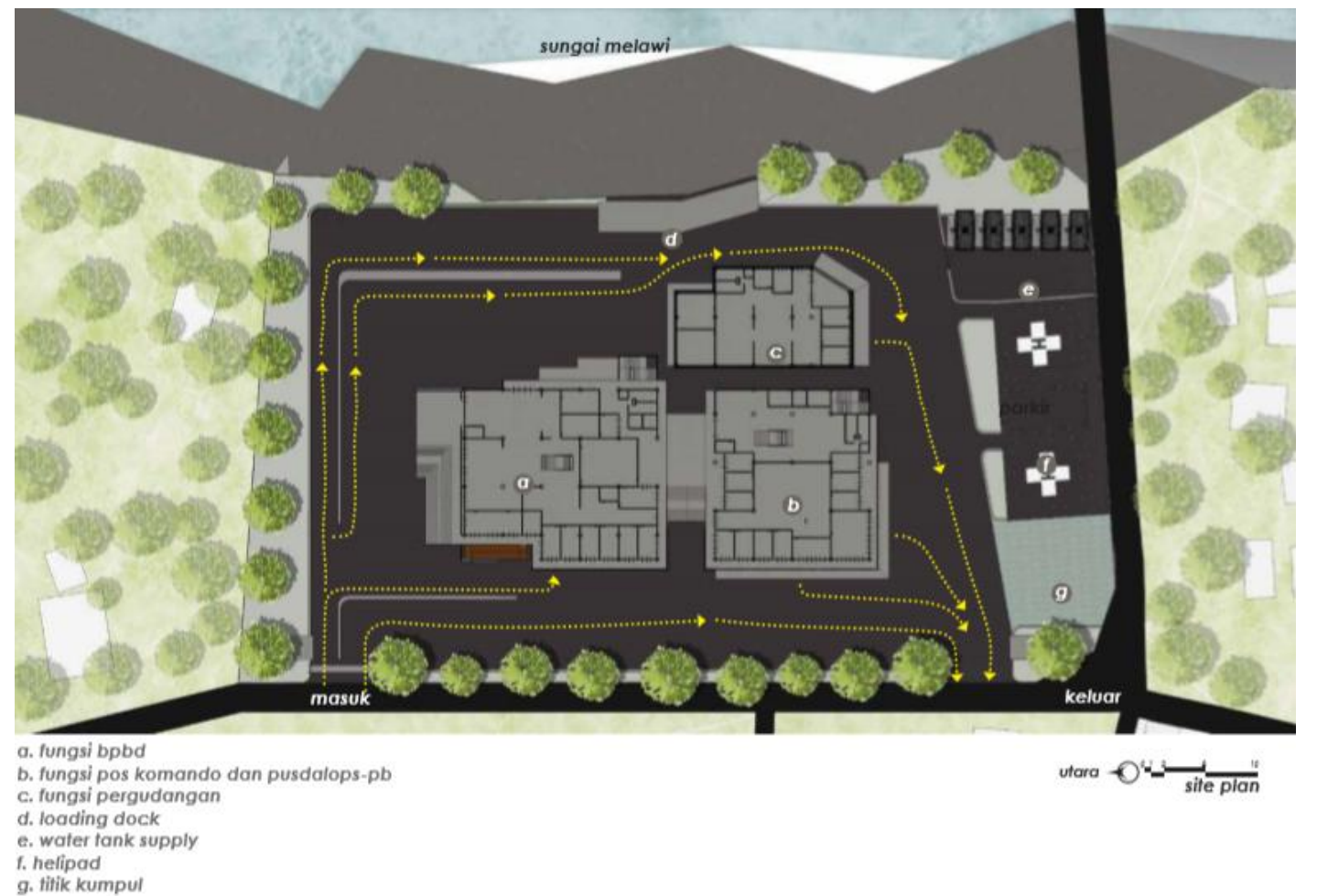

Gambar 5. Site Plan Pusat Penanggulangan Bencana Kabupaten Sintang

Sumber: Penulis, 2021 
Pusat Penanggulangan Bencana Kabupaten Sintang memiliki tiga massa bangunan yang terpisah dan saling terhubung dan memiliki jumlah denah yang berbeda pada setiap bangunan. Tiga massa bangunan tersebut adalah massa A sebagai fungsi BPBD dan bangunan utama, massa B sebagai fungsi Pos Komando dan Pusdalops-PB serta Pusat Pelatihan, dan massa C sebagai area pergudangan.

\section{A. BPBD}

Pada massa A Pusat penanggulangan Bencana Kabupaten Sintang terdiri dari tiga lantai. Pencapaian pada bangunan terhubung akses utama dan entrance bangunan dengan sarana tangga, massa A juga dapat dicapai melalui entrance sekunder yang terhubung dengan massa B. Lantai dasar ini bersifat publik dan dibagi dengan area servis, pada akses servis terpisah oleh sirkulasi.
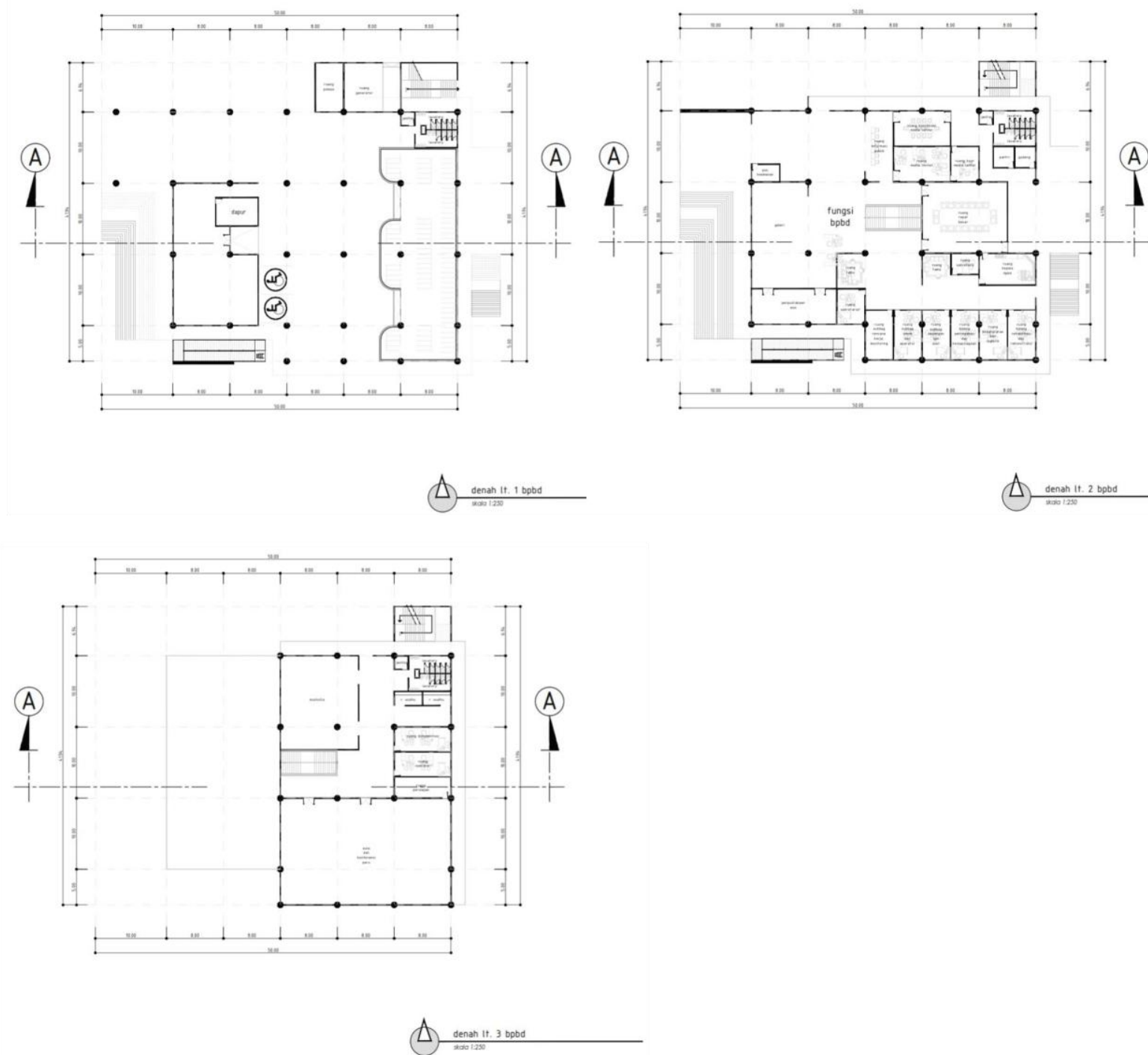

Gambar 6. Denah fungsi BPBD

Sumber: Penulis, 2021

Pada bagian depan diletakkan akses khusus yaitu ramp dan tangga untuk akses lantai 2 yang diarahkan menuju ruang lobby bangunan dan area penerimaan lain seperti ruang informasi publik, media center, galeri, dan perpustakaan mini. Lantai 2 terdiri dari area publik dan di dominasi oleh area privat dengan fungsi sebagai perkantoran dan ruang kerja, untuk mencapai ruang kerja dan area perkantoran, area publik dipisah oleh ruang komunal dan ruang tamu sebagai pembatas secara 
signifikan antara zona publik dan zona privat. Area perkantoran terletak di arah depan secara garis besar bangunan massa A. Lantai 2 di bagi menjadi tiga zona berupa zona privat, zona public serta zona servis yang dihubungkan serta dipisahkan oleh ruang komunal atau ruang penghubung.

\section{B. Pos Komando dan Pusdalops-PB}

Massa B merupakan gedung Pos Komando dan Posdalops-PB yang juga disertai dengan ruang Pusat Pendidikan dan Pelatihan, pada massa B juga diperuntukkan untuk Quick Response Area atau Tim Reaksi Cepat BPBD Kabupaten Sintang. Gedung ini memiliki fungsi utama sebagai penanganan cepat dan tanggap darurat dalam mitigasi bencana. Massa B ini memiliki fasilitas berupa area penyimpanan alat dan transportasi khusus.

Lantai satu massa B diperuntukkan sebagai tempat parkir kendaraan khusus seperti mobil komando, mobil pemadam kebakaran, kendaraan khusus. Lantai dua pada diperuntukkan untuk area fungsi Pos Komando dengan ruang-ruang kerja atau perkantoran administrasi. Lantai tiga diperuntukkan untuk Pusdalops-PB (Pusat Pengendalian Operasi Penanggulangan Bencana) dan beberapa ruang untuk asrama dan ruang kerja untuk Pusdalops-PB.

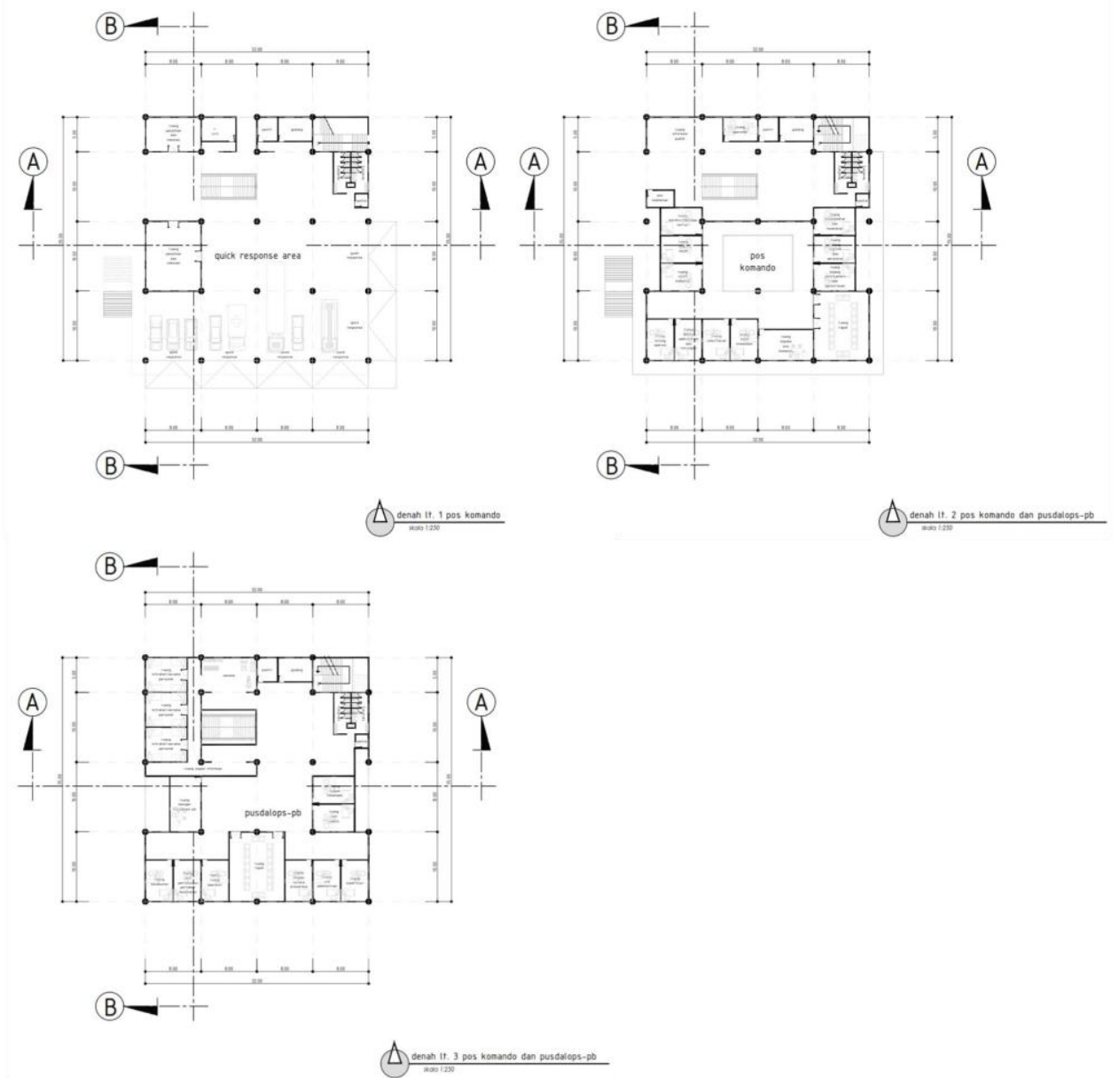

Gambar 7. Denah fungsi Pos Komando dan Pusdalops-PB

Sumber: Penulis, 2021

\section{Denah Fungsi Pergudangan}

Denah massa $\mathrm{C}$ merupakan area Pergudangan dan Logistik menjadi fokus utama, dalam massa bangunan ini adalah kegiatan yang bersifat servis tentang pendataan, penyimpanan, pendistribusian dan bongkar muat logistik dan peralatan yang bersifat menunjang kegiatan penanggulangan bencana. 
Lantai satu pada massa $\mathrm{C}$ diperuntukkan untuk penyimpanan logistik dan penyimpanan alat berat serta tempat bongkar muat dari kendaraan darat dan kendaraan air pada loading dock.

Akses penyimpanan barang di dalam bangunan dilengkapi dengan lift barang dan lift hidrolik dapat menaikkan kendaraan Forklift agar memudahkan dalam menaikkan barang pada lantai satu dan lantai dua. Bangunan belakang. Massa $\mathrm{C}$ terdapat ruang bongkar muat, dan ruang penyimpanan peralatan khusus dan logistik khusus berupa obat-obatan dan bahan kimia maupun vaksin.
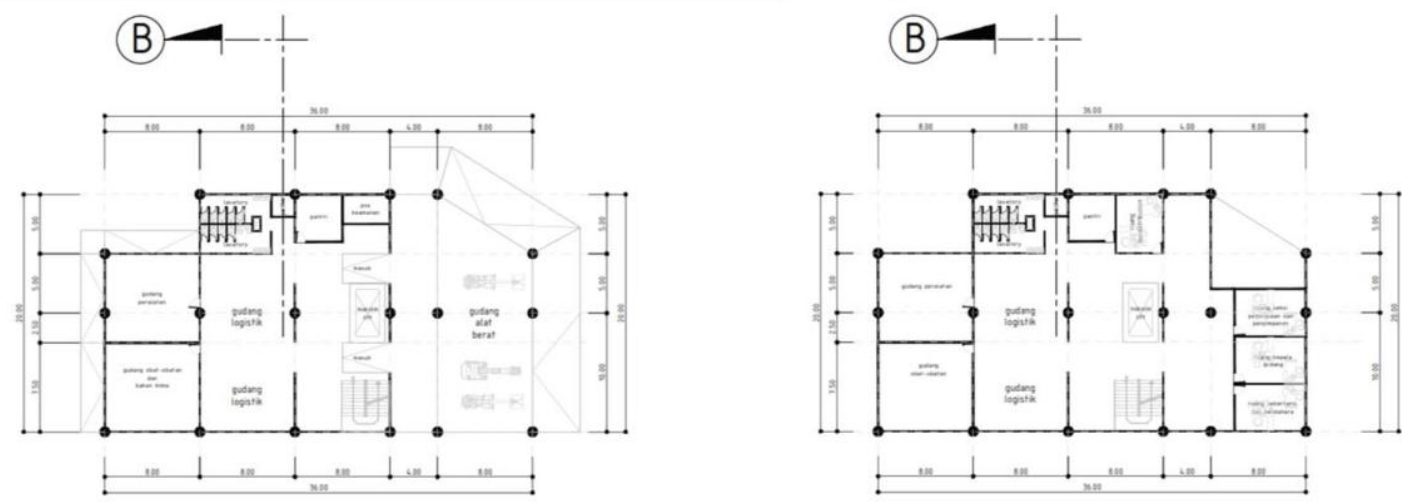

Gambar 8. Denah fungsi Pergudangan

Sumber: Penulis, 2021

Tampak gedung A memiliki konsep bentuk yang memiliki penekanan pada tata ruang, konsep ide dengan tuntutan efektifitas ruang. Perpaduan unsur garis-garis vertikal sebagai bentuk secondary skin sebagai respon terhadap pencahayaan yang tidak masuk secara langsung ke bangunan. Tampak massa B memiliki bentuk yang mengadopsi dari bentukan dasar yaitu persegi dan menggunakan fasad vertikal sebagai secondary skin.

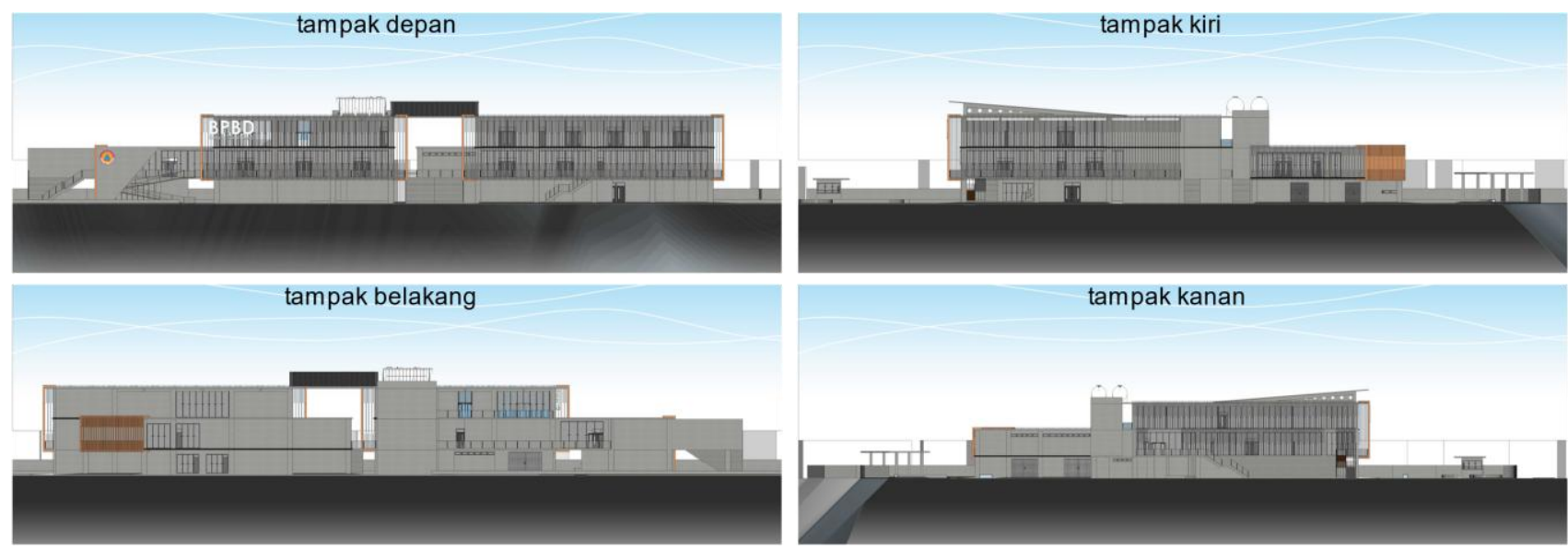

Gambar 9. Tampak Bangunan

Sumber: Penulis, 2021

Tampak dari massa B terdapat ruang-ruang kendaraan khusus dan menggunakan struktur kolom yang besar menegaskan bentuk. Tampak massa $\mathrm{C}$ memiliki konsep bentuk juga mengadopsi dari bentuk dasar dengan beberapa pengurangan dan menciptakan selubung bangunan berupa permainan garis-garis vertikal sebagai pelindung dari sinar matahari langsung dan memaksimalkan sirkulasi udara. Pada bagian lantai dasar pintu utama ruang gudang terhubung langsung dengan area loading dock. 
Gambar potongan A-A memotong ke belakang meliputi bangunan utama fungsi BPBD dan fungsi Pos Komando keamanan beserta. Massa A dan massa B meliputi ruang-ruang perkantoran dan ruang Quick Response Area. Pada bagian massa B merupakan bangunan memiliki lantai tipikal sehingga ruang terpotong memiliki sifat ruang yang hampir sama. Pada Potongan B-B, potongan mengambil area tengah pada massa $\mathrm{B}$ dan massa $\mathrm{C}$, sehingga terlihat tampak pada area kendaraan khusus. Pada potongan ini juga tertampak potongan ruang-ruang massa $\mathrm{C}$ berupa area pergudangan.

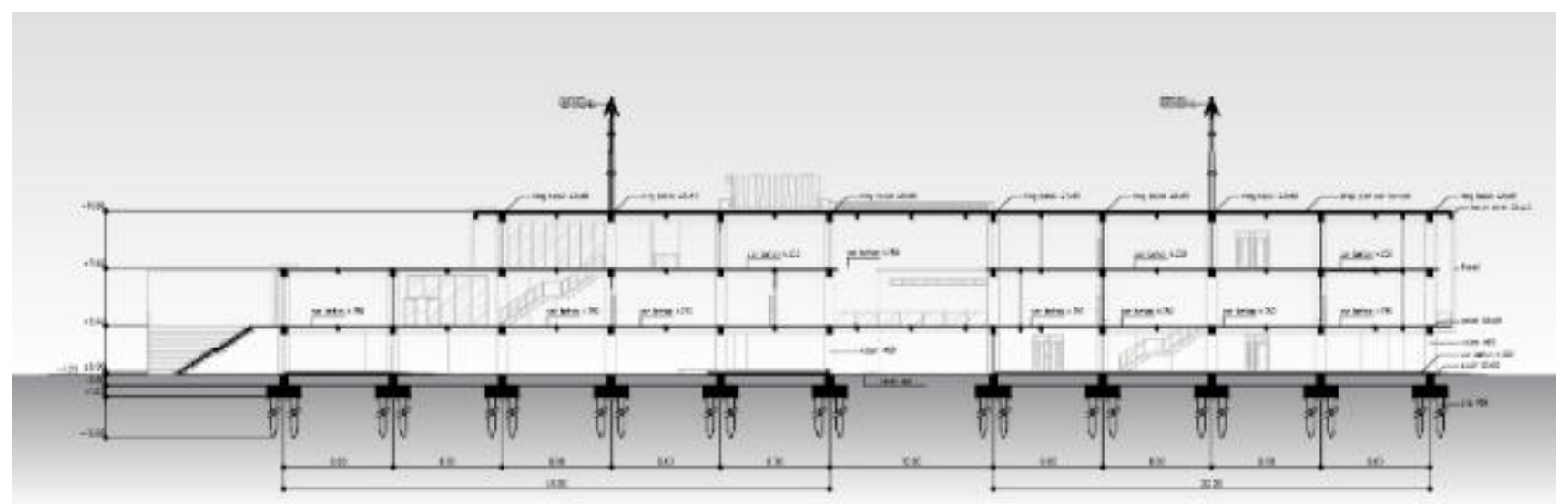

Gambar 10. Potongan A-A

Sumber: Penulis, 2021

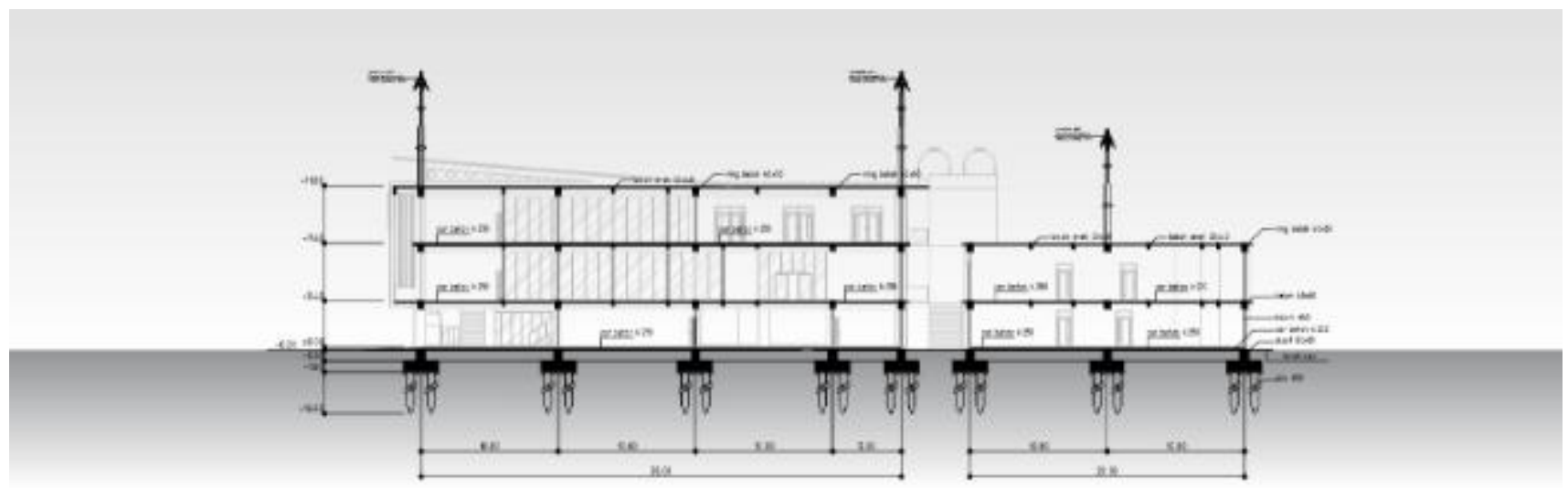

Gambar 11. Potongan B-B

Sumber: Penulis, 2021

Pusat Penanggulangan Bencana Kabupaten Sintang merupakan pusat dari segala bentuk kegiatan penanggulangan bencana di Kabupaten Sintang dengan konsep tata ruang yang dimaksimalkan dan efisiensi guna memaksimalkan sirkulasi udara dengan secondary skin yang dibuat vertikal. Pada bagian massa A dan massa B terdapat jalur sirkulasi yang saling terhubung dan sirkulasi kendaraan khusus. 


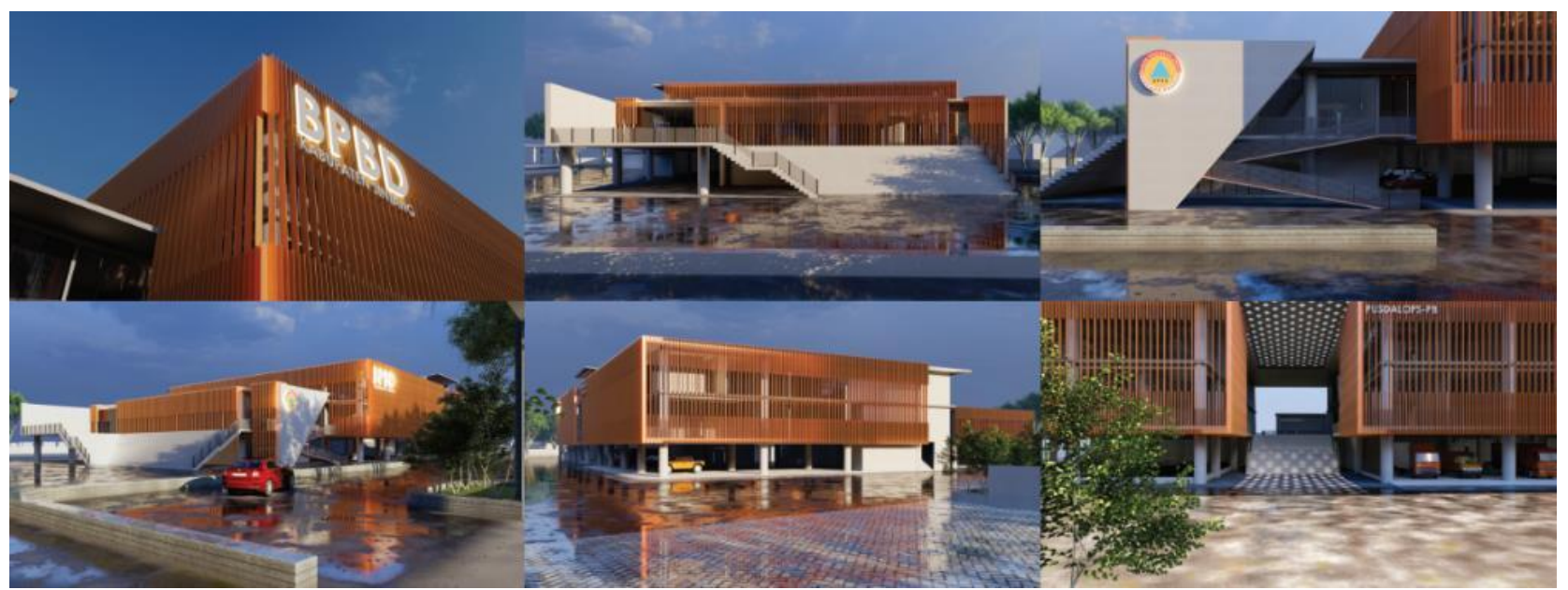

Gambar 12. Visualisasi Eksterior

Sumber: Penulis, 2021

Interior memperlihatkan suasana ruang-ruang yang ada pada Pusat Penanggulangan Bencana Kabupaten Sintang secara jelas sehingga dapat terlihat jenis-jenis pemilihan material perabot dan pemilihan warna ruang yang dapat mempresentasikan kondisi di dalam desain bangunan.

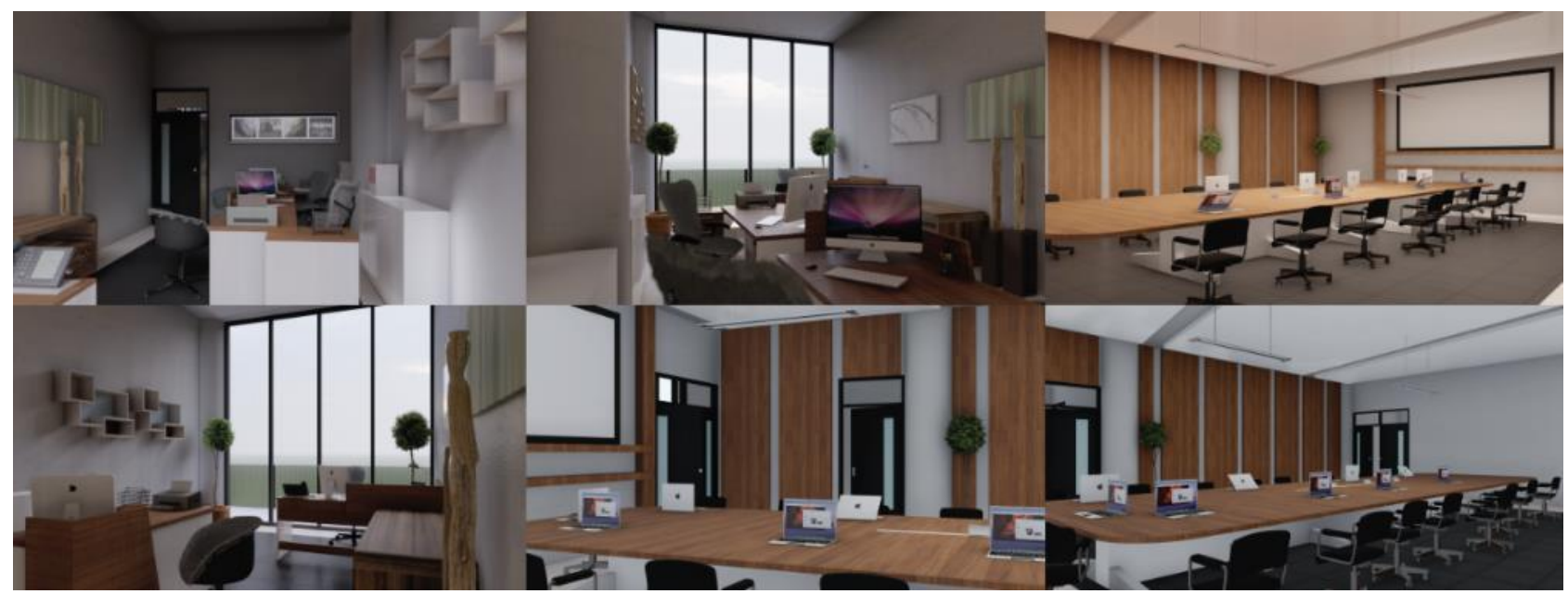

Gambar 13. Visualisasi Interior 1

Sumber: Penulis, 2021

\section{Kesimpulan}

Pusat Penanggulangan Bencana Kabupaten Sintang merupakan respon terhadap tidak adanya wadah yang menjadi pusat koordinasi terhadap tanggap bencana, dengan Pusat Penanggulangan Bencana Kabupaten Sintang dampak dari terjadinya bencana dapat diminimalisir dengan adanya fasilitas yang mewadahi dan terstandardisasi sehingga standar serta aktifitas di dalamnya dapat terpenuhi dan pelayanan dapat maksimal.

\section{Ucapan Terima Kasih}

Terima kasih kepada Tuhan YME karena berkat dan rahmat karunia-Nya penulis dapat menyelesaikan penulisan Jurnal ini. Kepada Orang Tua, Ayah dan Ibu yang telah banyak memberikan doa, dukungan dan pengorbanan baik secara moril maupun materil sehingga penulis dapat menyelesaikan Penulisan Jurnal ini serta Terima kasih kepada Dosen Pembimbing dan kepada pihakpihak lain yang secara langsung maupun tidak langsung membantu dalam bentuk moril maupun materil dalam menyelesaikan penulisan Jurnal ini. 


\section{Daftar Acuan}

Catanese, A. J., \& Snyder, J. C. (1989). Perencanaan Kota (2 ed.). Jakarta: Erlangga

Neufert, E. (1996). Data Arsitek Jilid 1. (P. W. Indarto, Ed.) (33 ed.). Jakarta: Erlangga

Neufert, E. (2002). Data Arsitek Jilid 2. (W. Hardani, Ed.) (33 ed.). Jakarta: Erlangga

Peraturan Kepala Badan Nasional Penanggulangan Bencana. (2008). Pedoman Penyusunan Rencana Penanggulangan Bencana. Jakarta. Diambil dari https://bnpb.go.id/uploads/24/peraturan-kepala/2008/perka-4-tahun-2008.pdf

Peraturan Kepala Badan Nasional Penanggulangan Bencana. (2009). Pedoman Standarisasi Peralatan Penanggulangan Bencana. Jakarta. Diambil dari https://bnpb.go.id/uploads/migration/pubs/24.pdf

Peraturan Presiden Republik Indonesia. (2019). Perpres RI Nomor 1 Tahun 2019 Tentang Badan Nasional Penanggulangan Bencana. Jakarta. Diambil dari https://peraturan.bpk.go.id/Home/Details/100440/perpres-no-1tahun-2019

Susetyo, H. (2012). Urgensi Undang-Undang Penanggulangan Bencana di Indonesia. Diambil dari https://esaunggul.ac.id/urgensi-undang-undang-penanggulangan-bencana-di-indonesia/

Undang-Undang Republik Indonesia. (2007). Undang-Undang Republik Indonesia Nomor 24 Tahun 2007 tentang Penanggulangan Bencana. Diambil dari https://bnpb.go.id/ppid/file/UU_24_2007.pdf 